\title{
Effect of method of weed control and insecticide (Lambda cyhalothrin) rates on the productivity of cowpea (Vigna unguiculata (L.) walp) in a southern Guinea savanna of Nigeria
}

\author{
Efeito do método de controle de ervas daninhas e taxas insecticidas \\ (Lambda cyhalothrin) sobre a produtividade de feijão-caupi \\ (Vigna unguiculata (L.) walp) em uma savanna Guinea do Sul em Nigéria
}

Emmanuel Oyamedan Imoloame ${ }^{1 *}$, Oluremi Solomon Osunlola ${ }^{1}$

\begin{abstract}
Field trials were conducted in two locations, at the Teaching and Research (T\&R) Farm of the College of Agriculture, Kwara State University and Ga-Alanu Village, Malete, in the 2015 cropping season. The objective this work was to evaluate the effect of herbicide application associated to the insecticide Lambda cyhalothrin on weed control, and yield of cowpea. The experiment consisted of 18 treatments arranged in a factorial scheme. The first factor was three insecticide rates

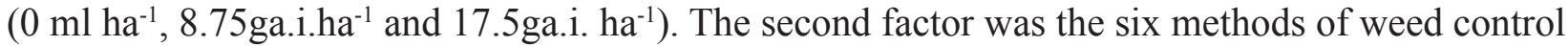
(pendimethalin at $1.5 \mathrm{~kg}$ a.i ha- ${ }^{-1}$, pendimethalin at $2.0 \mathrm{~kg} \mathrm{a}^{\mathrm{i}} \mathrm{ha}^{-1}$, pendimethalin at $1.5 \mathrm{~kg}$ a.i. ha ${ }^{-1}$ plus one supplementary hoe weeding (SHW), metholachlor + diuron at $1.5+0.6 \mathrm{~kg}^{\mathrm{a}} . \mathrm{i} \mathrm{ha}^{-1}$, hoe weeding at 3 and 6 weeks after sowing (WAS) and a weedy check). The treatments were laid out in randomized complete block design arranged factorially with 3 repetitions . Variables measured were weed density, weed dry matter, relative importance value of weed species, plant height, crop vigour, number of pods/plot and grain yield. Data collected was subjected to analysis of variance and means were separated using Least Significant Difference (LSD) at 5\% level of probability. Results

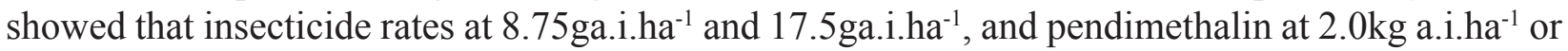
pendimethialin at $1.5 \mathrm{~kg}$ a.ha ${ }^{-1}$ plus one SHW promoted good growth and higher yield of cowpea. Keywords: pendimethalin, agrochemicals, metholachlor + diuron, hoeing, yield
\end{abstract}

Resumo - Experimentos de campo foram realizados em dois locais, na Fazenda de Ensino e Pesquisa (E \& P) da Faculdade de Agricultura, Universidade Estadual de Kwara, e na vila de Ga-Alanu, Malete, na temporada de cultivo de 2015. O objetivo deste trabalho foi avaliar o efeito da aplicação de herbicidas associada ao inseticida Lambda cyhalothrin no controle de ervas daninhas e na produção de feijão-caupi. $\mathrm{O}$ experimento consistiu em 18 tratamentos dispostos em um esquema fatorial. O primeiro fator foi a taxa de inseticida, em três níveis $\left(0 \mathrm{ml} \mathrm{ha}^{-1}, 8,75\right.$ ga.i.ha $^{-1}$ and 17,5 ga.i. ha $\left.{ }^{-1}\right)$. $\mathrm{O}$ segundo fator foi o método de controle de ervas daninhas, em seis categorias $\left(1,5 \mathrm{~kg}\right.$ a.i. ha ${ }^{-1} \mathrm{de}$ pendimetalina, 2,0 kg a.i. ha- ${ }^{-1}$ de pendimetalina, 1,5 $\mathrm{kg}$ a.i. $\mathrm{ha}^{-1}$ de pendimetalina associado a uma monda suplementar (MS) para eliminar as ervas daninhas, 1,5+0,6 kg a.i. ha-1 de metolacloro + diurão, monda suplementar para eliminar as ervas daninhas na $3^{\mathrm{a}}$ e $6^{\mathrm{a}}$ semanas após a semeadura (SAS) e uma checagem de ervas daninhas). Os tratamentos foram distribuídos em delineamento de blocos completos aleatorizados fatorialmente organizados com 3 repetições. As variáveis medidas foram a densidade da erva daninhas, a matéria seca das ervas daninhas, o valor de importância relativa

Received: March 07, 2017. Accepted: October 09, 2017.

${ }^{1}$ Crop Production Department, College Of Agriculture, Kwara State University, Malete, P.m.b. 1530, Zip Code 241104, Ilorin, Kwara State, Nigeria. E-mail: oyaimoloame@yahoo.com 
das espécies de ervas daninhas, a altura da plantas, o vigor da cultura, o número de vagens/parcela e o rendimento de grãos. Os dados coletados foram submetidos à análise de variância e as médias foram separadas com base na menor diferença significativa (MDS) ao nível de probabilidade de 5\%. Os resultados mostraram que as taxas de 8,75 ga.i.ha $^{-1}$ e 17.5 ga.i.ha ${ }^{-1}$ de inseticidas, e 2,0 kg a.i. ha ${ }^{-1}$ de pendimetalina, ou $1,5 \mathrm{~kg}$ a.i. $\mathrm{ha}^{-1}$ de pendimetalina associado a uma MS, promoveram um bom crescimento e maior rendimento de feijão-caupi.

Palavras-chave: pendimetalina, agroquímicos, metolacloro + diuron, monda, rendimento

\section{Introduction}

Cowpea (Vigna unguiculata (L) Walp) is a leguminous crop native of the drier regions (Jefferson, 2005). Total worldwide production of cowpea is estimated at 3.3 million tons of dry grain of which $64 \%$ is produced in Africa (FAO, 2001). Conservatively, an estimated area of 12.5 million hectares is planted annually to cowpea in the world. About 9.8 million hectares out of this is planted in West Africa, making it the region with the largest production and consumption of cowpea in the world (CGIAR, 2001).

Rural families derive food, animal fodder (Rachie, 1985; Tarawali et al., 1997; Asiwe, 2007a, 2008) and cash from the production of cowpea (Quin, 1997; Asiwe, 2007b). Cowpea is a primary source of plant protein. It contains $23 \%$ protein, $1.3 \%$ fats, $67 \%$ carbohydrate, $1.8 \%$ fiber and $8.9 \%$ water (Jefferson, 2005). In many parts of West Africa, where cowpea is very popular and is a staple food, it is utilized to fortify cassava, plantain, cereal-based meals and yoghurt. Cowpea is also important for controlling soil erosion and fixing atmospheric nitrogen into the soil thereby reducing nitrogen requirements for its growth (Longdale et al., 1992; Mulongoy, 1995; Asiwe, 2009b). Davis et al. (2005) reported that cowpea intercropped with sorghum or millet can fix between 25 to $45 \mathrm{~kg}$ $\mathrm{ha}^{-1} \mathrm{~N}$, capable of reducing the nitrogen fertilizer requirements for cereals by half.

Cowpea usually suffers serious pests and diseases infestation which constitute a major limitation to its production (Singh et al., 2000; Asiwe et al., 2005; Asiwe, 2009b). Amatobi et al. (2005) also reported that field insect pests could even cause loss on yield of cowpea. One major constraint to the increased and sustainable production of cowpea is the damage caused by field insect pests, particularly, during the flowering and post-flowering growth stages (Singh, 1990; Obeng-Ofori, 2007). Among the most serious pests species attacking cowpea include flower thrips (Megalurothrips sjostedti Tryb), pod borers (Murica Vitrata $\mathrm{Fab}$ ) and a complex of pod and seed - sucking bugs such as Riptortus dentipesfab, Clavigralla tomentosicollisstal., Anoplocnemis Curvipes Fab and Nezara Viridula L. (Jackai and Daoust, 1986; Badii et al., 2008). Ogunwolu (1990) reported that Maruca testulalis Geyer, reduced cowpea yield by $72.1 \%$ in 1985 and $48.1 \%$ in 1986 . Also, Singh and Jackai (1985) and Singh et al. (2003) reported that sixty to eighty percent of grain losses in cowpea have been attributed to the activities of insect. All these insect damage caused on cowpea account for the reason its production is considered too risky an investment by growers and part of the cause of the low yield of 200 to $300 \mathrm{~kg} \mathrm{ha}^{-1}$ obtained by formers in Nigeria. (Rusoke and Rubaihayo, 1994). Besides that, weeds aggravate disease and insect pest problems by serving as alternative hosts. Besides that, weedscan reduce the cowpea yield, and deteriorate the quality of the product. Yield loss in cowpea due to weeds was 12.7 to $60 \%$ (Li et al., 2004). Tripathi and Singh (2001) reported that the presence of weeds in cowpea reduced yield at $82 \%$. Akinyemiju and Olaifa (1991), reported that reduced cowpea biomass, flowers, pods and grain yields were associated with cowpea plots where weeds and insect pests were not controlled. Weed control without insect 
pest control led to more than $90 \%$ reduction in cowpea yield and yield components. On the other hand, insect pests control without weed control resulted in 70\% loss in yields of cowpea (Ezuueh and Amusah, 1988).

Higher cowpea yield can be attained by recommending appropriate effective and efficient pest and weeds control methods. Most farmers use insecticides to control insect pests on their farms (Solomon and Mumuni, 2016; The Guardian, 2016). Research evaluating the us of insecticide to control insect pests include that of Badii et al. (2010) who concluded that lambda cyhalothrin based formulations at $2.51 \mathrm{ha}^{-1}$ can control insect attack, ensuring the growth, development and yield of cowpea crop. Besides that, application rates of between 0.4 to 0.81 ha $^{-1}$ (Dugje et al., 2009) or 0.200 to $0.500 \mathrm{ha}^{-1}$ (manufacturer's recommendation) of lambda cyhalothrin has been recommended for effective insect control on cowpea. To control weeds in this crop, two hand weeding at 3 and 6 weeks after sowing (WAS), and the use of herbicides have been reported to be effective in thecontrol of weeds in cowpea (Chatta et al., 2007; Dugje et al., 2009; Takim and Uddin, 2010). In order to prevent the abuse of the use of pesticides, it is necessary to determine the specific minimum rate of lambda cyhalothrin and a better weed control method that will control effectively both insects and weeds. The objective this work was to evaluate the effect of herbicide application associated to the insecticide lambda cyhalothrin on weed control, and yield of cowpea.

\section{Materials and methods}

Field trials were conducted at two locations, at the Teaching and Research (T\&R) Farm of the College of Agriculture, Kwara State University and Ga-Alamu Village, a farming community, a few kilometers from the T\&R farm of the university. Both of them are located in Malete (Lat.08 $71^{\prime} \mathrm{N}$; Long.04⒋'E.) in Moro Local Government Area of Kwara State in the Southern Guinea Savanna ecological zone of Nigeria.

The total amount of rainfall recorded in 2015 was $1010.5 \mathrm{~mm}$, with the month of September having the highest rainfall, while January, February, April and August had low rainfall (Figure1). The experimental area of T\&R farm was cropped with cowpea the previous year in 2014, and has been put under cultivation every

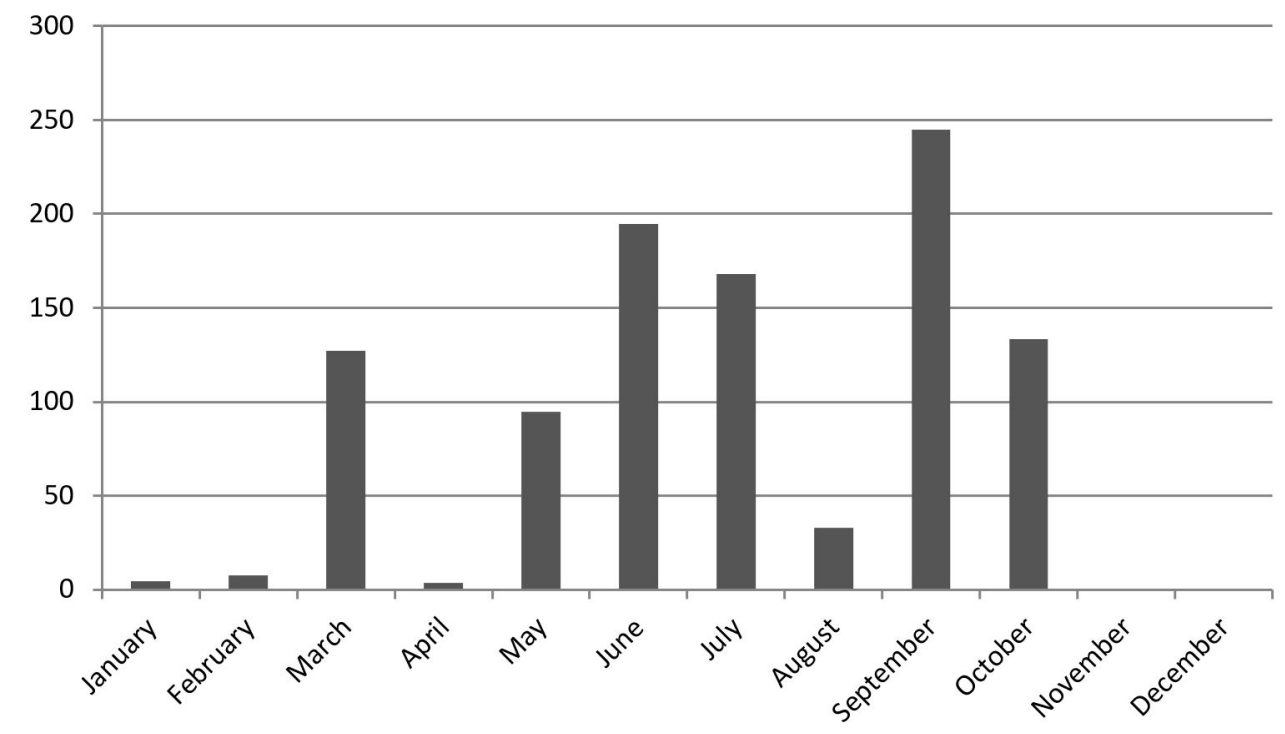

Figure 1. Rainfall figures (mm) for 2015 in Ilorin.

Source: Teaching and Research Farm of Faculty of Agriculture, University of Ilorin. 
year, while the land at Ga-Alamu was left fallow for 2-3 years before the conduct of this experiment. Physico-Chemical Analysis of the soil of the Experimental Sites showed that the nitrogen and available phosphorus content of the soil in both locations was low and inadequate. However, the potassium content of the soil at Ga-Alanu was higher than that of T\&R farm (Table 1).

The experimental area in each lacation was $1,127.5 \mathrm{~m}^{2}$. Before conducting this experiment, the soil was plowed, harrowed, leveled and the plots demarcated. The plot size was $4.0 \times 4.0 \mathrm{~m}$ leaving a distance of $1 \mathrm{~m}$ and $0.5 \mathrm{~m}$ between replication and sub-plot (the sub divisions in each block measuring $4 \mathrm{~m} \times 4 \mathrm{~m}$ each) respectively. A fertilization with NPK 15-15-15 was applied and raked into the soil in each plot at the rate of $20 \mathrm{~kg} \mathrm{ha}^{-1}$ before planting. Sowing was performed at the Ga-Alanu and T\&R farm on the $28^{\text {th }}$ and $29^{\text {th }}$ of July, 2015 respectively. Three seeds of cowpea, variety IAR-48, were planted per hole at a spacing of $75 \times 50 \mathrm{~cm}$. After emergence, cowpea plants were thinned to 2 plants/hole to give a plant population of 53,333 plant ha ${ }^{-1}$. Herbicide was applied pre-emergence a day after sowing with a CP15 knapsack sprayer and a green nozzle which were calibrated to apply at an rate of $250 \mathrm{~L} \mathrm{ha}^{-1}$. Similarly, insecticide lambda cyhalothrin was applied to the cowpea 4 times from pre-flowering to flowering stages of crop growth on 27 th of August, 11th and 25th of September, and 9th of October, 2015.

The experiment consisted of 18 treatments arranged in a factorial scheme. The first fact was three insecticide rates $\left(0 \mathrm{ml} \mathrm{ha}^{-1}, 8.75 \mathrm{ga}^{-i . h a^{-1}}\right.$ and 17.5ga. i. ha $\left.{ }^{-1}\right)$. The second factor was the six methods of weed control (pendimethalin at $1.5 \mathrm{~kg}$ a.i ha-1, pendimethalin at $2.0 \mathrm{~kg}$ a.i ha ${ }^{-1}$, pendimethalin at $1.5 \mathrm{~kg}$ a.i. ha ${ }^{-1}$ plus one supplementary hoe weeding (SHW), metholachlor + diuron at $1.5+0.6 \mathrm{~kg}$ a.i ha ${ }^{-1}$, hoe weeding at 3 and 6 weeks after sowing (WAS) and a weedy check). The treatments were laid out in randomized complete block design arranged in a factoral scheme with 3 repetitions. Harvesting

Table 1. Physico-chemical properties of soil $(0-30 \mathrm{~cm})$ collected from the experiment sites in 2015.

\begin{tabular}{lcc}
\hline \multicolumn{1}{c}{ Soil properties } & T\&R farm & Ga-Alamu \\
\hline Physical perties & & \\
Sand $(\mathrm{g} / \mathrm{kg})$ & 812 & 75.2 \\
Silt $(\mathrm{g} / \mathrm{kg})$ & 94.0 & 154.0 \\
Clay $(\mathrm{g} / \mathrm{kg})$ & 94.0 & 94.0 \\
Textural Class & Loamy Sand & Loamy Sand \\
Chemical Properties & & \\
PH in water $(1: 2.5)$ & 6.2 & 6.20 \\
Total organic Carbon $(\mathrm{g} / \mathrm{kg})$ & 13.2 & 9.8 \\
Total Nitrogen $(\mathrm{g} / \mathrm{kg})$ & 1.4 & 1.1 \\
Available P mg/kg & 6.6 & 6.5 \\
Exchangeable Cation $(\mathbf{C} / \mathbf{m o l} / \mathbf{k g})$ & & \\
$\mathrm{K}$ & 0.17 & 0.32 \\
$\mathrm{Mg}$ & 2.23 & 6.8 \\
$\mathrm{Ca}$ & 1.4 & 2.7 \\
Exch. Micro Nutrients $\left(\mathbf{C m o L ~} \mathbf{~ k g ~}{ }^{-1}\right)$ & & \\
$\mathrm{Mn}$ & 184.0 & 187.0 \\
$\mathrm{Fe}$ & 82.0 & 102.0 \\
$\mathrm{Cu}$ & 1.68 & 2.07 \\
$\mathrm{Zn}$ & 1.92 & 5.53 \\
$\mathrm{Na}$ & 0.18 & 0.16 \\
\hline
\end{tabular}


of cowpea was done on a net plot of $8 \mathrm{~m}^{2}$ and the two border rows on either sides of the plot was discarded to minimize error.

Weed density was determined at 6 and 12 WAS, by counting the total number of weed species per unit area (quadrat) in each plot. Weed cover score was visually assessed at 6,9 and 12 WAS using a scale of 1 to 10 , where 1 represented no weed cover and 9 represented complete weed cover. Weed dry weight $\left(\mathrm{kg} \mathrm{ha}^{-1}\right)$ was obtained by taking weed samples at random from a $1 \mathrm{~m}^{2}$ placed randomly in 3 locations in each plot at 6 and 12 WAS. The weeds were gathered together, put in a paper bags, and dried at a temperate of $80^{\circ} \mathrm{C}$ for 2 days to a constant weight. The oven-dried weight in gram was converted to $\mathrm{kg} \mathrm{ha}^{-1}$ for each plot.

The Relative Importance Value (RIV\%) of each species infesting the experimental plots was determined after the weeds were collected from the quadrat and before they were oven dried. The RIV was computed as the mean of the percentage of relative frequency and relative density for each species according to Wentworth et al. (1984).

$\mathrm{RIV}=\frac{\mathrm{RD}+\mathrm{RF}}{2}$

Relative density (RD) was determined by dividing the total number of number of individuals of a weed species in all the quadrats divided by the total number of individual of all the weed species in all the quadrats multiplied by 100 . Percentage relative frequency was calculated as the number of occurrence of a species in all the quadrat divided by the total of occurrence of all species in all the quadrats multiplied by 100 (Das, 2011)

The crop vigour score was assessed visually using a scale of 1 to 10 , where 1 represented complete death of the plant, and 10 represented most vigorous plants. Plant height was determined by measuring the height of 5 randomly selected plant per plot at 6,9 and 12 WAS, using a meter rule from the soil level to the apical bud of the plant. The number of pods/plant was determined by counting the number of pods in 5 plants randomly selected in each plot and the average of the total number of pods was recorded. Grain yield was determined by weighing the grains harvested from each net plot (this is the area covering the four inner rows out of the six rows of the gross plot area of $4 \mathrm{mx} 4 \mathrm{~m}$. The remaining two outer rows were discarded to reduce error) which was converted to kilograms per hectare using the formula below:

Grain Yield kg $/$ ha $=\frac{\text { Grain yield } / \text { Net Plot } \times 10,000}{\operatorname{Net} \operatorname{Plot}\left(\mathrm{m}^{2}\right)}$

The data collected was subjected to analysis of variance using Statistical Analysis System (SAS) package and were F value was significant, the means were separated using the Least Significant Difference (LSD) at 5\% level of probability.

\section{Results and discussion}

\section{Relative Importance Value (RIV) at the experimental site}

The relative importance values of the different species of weeds that occurred at the two locations are presented in (Table 2). A total of 26 weeds species was recorded across the two locations. In the T\&R farm, a total of 11 weed species belonging to 5 families were identified at 6 WAS. Out of this, 7 (63.6\%) species were grasses, while $3(27.3 \%)$ were broad-leaved and $1(9.1 \%)$ was a sedge. However at harvest, 17 weed species were identified made up of $6(35 \%)$ grass, $7(41.2 \%)$ broad-leaved and $4(23.5 \%)$ sedges. The most dominant weed species at the T\&R farm at 6 WAS was Paspalum scrobiculatum, followed by Brachiaria alata, Rottboellia cochinchinensis, Seteria barbata in the descending order. At 12 WAS, a similar trend was observed with Paspalum scrobicutatum becoming the dominant species followed by Rottboellia cochinchinensis, Brachiaria alata, Seteria barbata and Vernonia galamensis in the descending order.

On the order hand, 15 different weed species belonging to 9 weed families were present at 
Table 2. Relative importance value (RIV\%) of weed species at the experimental site, 2015.

\begin{tabular}{|c|c|c|c|c|}
\hline \multirow{2}{*}{ Weed Species } & \multirow{2}{*}{ Family } & \multicolumn{2}{|c|}{$T \& R$} & \multirow{2}{*}{$\begin{array}{c}\text { Ga-Alamu } \\
\text { 6 WAS }\end{array}$} \\
\hline & & 6 WAS & 12 WAS & \\
\hline Setaria barbata (Lam.) Kunth & Poaceae & 11.1 & 6.4 & 12.6 \\
\hline Rottboellia Cochinchinensis (Lour.) Clayton & Poaceae & 13.4 & 15.1 & - \\
\hline Paspalum Scrobiculatum Linn & Poaceae & 37.6 & 33.1 & 5.8 \\
\hline Dactyloctenium aegyptium (Linn.) P.Beauv. & Poaceae & 1.4 & 0.9 & - \\
\hline Grass (Unidentified) & Poaceae & 2.1 & 3.1 & - \\
\hline Brachiaria alata (Shumach) C.E. Hubbard & Poaceae & 13.9 & 8.5 & - \\
\hline Digitaria horizontalis Willd. & Poaceae & 1.4 & - & - \\
\hline Commelina benghalensis & Commelinaceae & 7.3 & 3.5 & 11.1 \\
\hline Daniellia oliveri (Rolle) Hutch. & Leguminosae & 1.4 & - & 4.9 \\
\hline Vernonia galamensis & Asteraceae & 7.8 & 6.3 & 11.4 \\
\hline Portulaca oleracea Linn & Portulacaceae & - & 2.8 & - \\
\hline Gomphrena celosoides Mart. & Amaranthaceae & - & 3.0 & - \\
\hline Leucas martinicensis (Jacq.) & Lamiaceae & - & 1.0 & - \\
\hline Hyptis suaveolens Poit & Lamiaceae & - & 3.9 & - \\
\hline Tridax procumbens Linn & Asteraceae & - & 0.8 & 1.7 \\
\hline Cleome viscosa $\mathrm{L}$. & Cleomaceae & - & - & 11.5 \\
\hline Sclerocarpus Africanus & Asteraceae & - & & 1.2 \\
\hline Blepharis maderaspatensis( (Linn) Heinea \& Roth & Acanthaceae & - & - & 1.2 \\
\hline Chamacrista mimosoides & Leguminosae & - & - & 2.2 \\
\hline Aspilia bussei O. Hoffm. \& Muschi & Asteraceae & - & - & 2.6 \\
\hline Senna obtusitolia (L) Irwin \& Barneby & Leguminosae & - & - & 4.5 \\
\hline Fimbristylis ferruginea (Linn) VahL & Cyparaceae & - & - & 4.9 \\
\hline Cyperus. rotundus Linn. & Cyparaceae & - & 1.5 & - \\
\hline Cyperus esculentus Linn & Cyparaceae & - & 3.5 & 14.2 \\
\hline Killinga erecta Schumach Var. erecta & Cyparaceae & 4.5 & 6.0 & - \\
\hline Pycreus lanceolatus (poir.) C, B. Cl. & Cyparaceae & - & 1.0 & 10.3 \\
\hline
\end{tabular}

Ga-Alanu at 6 WAS, out of which two $(13.3 \%)$ were grasses, ten $(66.7 \%)$ are broad-leaved and the rest three $(20.0 \%)$ are sedges. The most dominant weed species were Cyperus rotundus, Seteria barbata, Cleome viscosa, Vernonia galamensisand Commelina benghalensis in the descending order (Table 2). These dominant weeds could have competed more with cowpea at their respective location, leading to its significantly low yield at the T\&R farm. Gani et al. (2016) reported that the dominant weed flora in finger millet in the northern Guinea and Sudan savanna zone of Nigeria implies that they were more adaptive, more persistent and more competitive with the crop.

\section{Effect of Lambda cyhalothrin insecticide rates and method of weed control on weed cover score and weed density}

The different rates of lambda cyhalothrin insecticide had no significant effect on weed cover scores at 6 , and 12 WAS at T\&R farm and Ga-Alanu (Table 3). However, two hoes weeding at 3 and 6 WAS and pendimethalin at $2.0 \mathrm{~kg}$ a.i./ha gave weed cover score which was significantly lower than the weedy check but was comparable with other methods of weed control at 6 WAS at T\&R farm and Ga-Alanu. At 12 WAS pendimethalin at $1.5 \mathrm{~kg}$ a.i. ha ${ }^{-1}$ plus one SHW significantly reduced weed cover score at T\&R farm and Ga-Alanu at 6 WAS and their mean compared to the other methods of weed control, except two hoes weeding at T\&R farm. 
Table 3. Effect of Lambda cyhalothrin insecticide rate and methods of weed control on cowpea weed cover scores and weed density.

\begin{tabular}{|c|c|c|c|c|c|c|c|c|c|}
\hline \multirow[b]{3}{*}{ Insecticide (I)rate(o a.i./ha) } & \multicolumn{6}{|c|}{ Weed cover } & \multirow{2}{*}{\multicolumn{3}{|c|}{$\frac{\text { Weed density } / \mathrm{m}^{2}}{\text { 6 WAS }}$}} \\
\hline & \multicolumn{3}{|c|}{$6 \mathrm{WAS}^{1}$} & \multicolumn{3}{|c|}{12 WAS } & & & \\
\hline & T\&R & GA & Mean & T\&R & GA & Mean & T\&R & GA & Mean \\
\hline 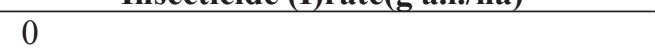 & 5.43 & 2.54 & 3.99 & 5.11 & 2.69 & 3.90 & 24.78 & 12.11 & 18.44 \\
\hline 8.75 & 6.31 & 3.20 & 4.75 & 5.25 & 2.47 & 3.86 & 23.17 & 10.39 & 16.78 \\
\hline 17.5 & 6.67 & 2.92 & 4.79 & 5.67 & 3.11 & 4.39 & 18.22 & 15.78 & 17.00 \\
\hline $\operatorname{LSD}(0.05)$ & 1.71 & 0.95 & 1.06 & 1.30 & 0.85 & 1.08 & 9.61 & 10.62 & 10.12 \\
\hline \multicolumn{10}{|l|}{ Methods of Weed Control(WC) } \\
\hline Weeding $3 \& 6$ WAS & 4.66 & 1.60 & 3.13 & 2.39 & 1.28 & 1.83 & 5.69 & 5.67 & 5.68 \\
\hline Melachlor+Diuron $1.5+0.6 \mathrm{~kg}$ a.i. $/ \mathrm{ha}$ & 4.50 & 1.30 & 2.90 & 5.06 & 1.83 & 3.44 & 22.90 & 5.11 & 14.01 \\
\hline Pedimethalin $1.5 \mathrm{~kg}$ a.i./ha & 5.81 & 2.42 & 4.12 & 7.11 & 1.72 & 4.42 & 24.70 & 7.78 & 16.24 \\
\hline Pedimethalin $1.5 \mathrm{~kg}$ a.i. $/ \mathrm{ha}+$ one SHW $6 \mathrm{WAS}$ & 6.89 & 1.58 & 4.23 & 2.33 & 1.17 & 1.75 & 24.83 & 9.44 & 17.14 \\
\hline Pedimethalin $2.0 \mathrm{~kg}$ a.i./ha & 5.94 & 1.21 & 3.58 & 5.83 & 1.39 & 3.61 & 18.31 & 4.33 & 11.32 \\
\hline Weedy Check & 9.00 & 9.22 & 9.11 & 9.33 & 9.17 & 9.25 & 35.90 & 44.22 & 40.06 \\
\hline LSD (0.05) & 2.42 & 1.36 & 1.89 & 1.83 & 1.20 & 1.51 & 13.59 & 15.02 & 14.30 \\
\hline \multicolumn{10}{|l|}{ Interaction } \\
\hline $\mathrm{I}^{*} \mathrm{WC}$ & NS & NS & & NS & NS & & NS & NS & \\
\hline
\end{tabular}

The interaction between insecticide and method of weed control was not significant in both locations and their means (Table 3). Weed density was not significantly affected by lambda cyhalothrin application rates. However, methods of weed control had an effect on this parameter significantly only at 6 WAS as pendimethalin at $2.0 \mathrm{~kg}$ a.i. ha ${ }^{-1}$ and 2 hoes weeding significantly reduced weed density which was comparable with the other method of weed control but significantly lower than the weedy check. The interaction between insecticide and method of weed control was not significant (Table 3). This result suggests that pendimethalin at $1.5 \mathrm{~kg}$ a.i. ha-1 plus one SHW, pendimethalin at $2.0 \mathrm{Kg}$ a.i. ha ${ }^{-1}$ and two hoe weedings at 3 and 6 WAS provided more efficient, season-long and better weed control than other methods as they significantly reduced both weed cover and density.

\section{Effect of Lambda cyhalothrin insecticide rates and method of weed control on weed dry matter}

Weed dry matter was significantly affected at Ga-Alanu and the mean at 6 and 12 WAS (Table 4). The lower (8.75g a.i. ha-1) insecticide rate resulted in significantly lower weed dry matter compared to higher $\left(17.5 \mathrm{~g}\right.$ a.i.ha $\left.{ }^{-1}\right)$ rate and plots not treated with insecticide. At 12 WAS, both rates of insecticide resulted in significantly lower weed dry matter than the plots without insecticide treatment at Ga-Alanu (Table 4). Weed dry matter was significantly affected in T\&R farm and Ga-Alanu at 6 and 12 WAS by the method of weed control. Two hoe weeding and pendimethalin at $1.5 \mathrm{~kg}$ a.i.ha ${ }^{-1}$ plus one SHW supported comparable significantly lower weed dry matter compared to the other methods of weed control in $\mathrm{T} \& \mathrm{R}$ farm. The same trend was recorded in Ga-Alanu and the mean with the other weed control methods giving comparable significantly higher weed dry matter, except, pendimethalin at $2.0 \mathrm{~kg}$ a.i. ha ${ }^{-1}$ at 6 WAS.

Weed dry matter continued to be kept significantly low compared to the other treatments at $T \& R$ farm and Ga-Alanu at 12 WAS by two hoe weeding, pendimethalin at $1.5 \mathrm{~kg}$ a.i.ha ${ }^{-1}$ plus one SHW and pendimethalin at $2.0 \mathrm{~kg}$ a.i. ha-1. Weedy check supported significantly higher weed dry matter both at 6 and 12 WAS in T\&R farm and Ga-Alanu.

The interaction between insecticide rate and method of weed control was not significant 
Table 4. Effect of Lambda cyhalothrin insecticide and methods of weed control on cowpea Weed dry matter $\left(\mathrm{kg} \mathrm{ha}^{-1}\right)$.

\begin{tabular}{|c|c|c|c|c|c|c|}
\hline \multirow[b]{3}{*}{ Insecticide rate (I) (g a.i./ha) } & \multicolumn{6}{|c|}{ Weed dry matter } \\
\hline & \multicolumn{3}{|c|}{$6 \mathrm{WAS}^{1}$} & \multicolumn{3}{|c|}{12 WAS } \\
\hline & T\&R & GA & Mean & $\mathbf{T} \& \mathbf{R}$ & GA & Mean \\
\hline 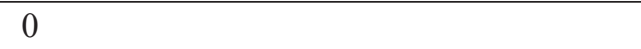 & 392.91 & 116.02 & 254.47 & 1048.54 & 60.93 & 554.74 \\
\hline 8.75 & 549.27 & 69.94 & 309.61 & 675.94 & 190.82 & 433.38 \\
\hline 17.5 & 441.09 & 157.77 & 299.43 & 663.89 & 84.26 & 374.07 \\
\hline $\operatorname{LSD}(0.05)$ & 206.68 & 78.12 & 142.4 & 485.68 & 119.74 & 302.71 \\
\hline \multicolumn{7}{|l|}{ Methods of Weed Control(WC) } \\
\hline Weeding 3 \& 6 WAS & 45.00 & 24.71 & 34.86 & 108.88 & 9.79 & 59.33 \\
\hline Melachlor+Diuron1.5+0.6 kg a.i./ha & 481.11 & 43.12 & 262.12 & 896.30 & 36.29 & 466.29 \\
\hline Pedimethalin 1.5 kg a.i./ha & 702.50 & 73.08 & 387.79 & 1287.46 & 152.97 & 720.21 \\
\hline Pedimethalin 1.5 kg a.i./ha+one SHW 6WAS & 276.08 & 67.26 & 171.67 & 183.34 & 21.88 & 102.61 \\
\hline Pedimethalin 2.0 kg a.i./ha & 347.38 & 96.67 & 222.02 & 725.97 & 59.61 & 392.79 \\
\hline Weedy Check & 914.49 & 382.63 & 648.56 & 1574.80 & 391.49 & 983.14 \\
\hline LSD (0.05) & 292.29 & 110.48 & 201.39 & 686.86 & 169.33 & 428.10 \\
\hline \multicolumn{7}{|l|}{ Interaction } \\
\hline $\mathrm{I} * \mathrm{WC}$ & NS & NS & & NS & NS & \\
\hline
\end{tabular}

(Table 4). The lower weed dry matter in the plots treated with lambda cyhalothin insecticide compared tothe untreated plots could be due to the ability of the insecticide especially at the lower rate to effectively control pest attack. This fact could have promoted good crop growth which in turn could have enhanced the ability of cowpea to smother weed through early canopy closure.

Pendimethalin at $1.5 \mathrm{~kg}$ a.i. ha ${ }^{-1}$, plus one SHW gave season-long weed control, by reducing weed cover score, weed density and weed dry matter significantly compared to other weed control. The effect of this method of weed control was comparable with pendimethalin at $2.0 \mathrm{~kg}$ a.i.ha ${ }^{-1}$ and two hoes weeding at 3 and 6 WAS. Pendimethalin herbicide is known to be effective against itch grass (Rottboellia Cochinchinensis (Lour) W. Clayton), which was one of the most dominant weed species in T\&R farm. One SHW integrated with pendimethalin at $1.5 \mathrm{~kg}$ a.i. ha ${ }^{-1}$ enhanced the ability of the herbicide to control weeds in both location and their mean.

Amosun et al. (2016) reported that the efficacy of tank mixture of pendimethalin plus atrazine controlled weeds better than atrazine plus metolachlor in the Guinea savanna due to the preponderance of Rottboellia cochinchinensis which is susceptible to pendimethalin herbicide. The above result is similar to the findings of Imoloame (2014) and Peer et al. (2013) that two hand weedings and herbicide integrated with hand weeding recorded far superior yields of soybean seed. Also, many researchers like Veeramani et al. (2001) held similar views and reported more pods with integrated use of herbicides with hand weeding.

\section{Effect of Lambda cyhalothrin rates and methods of weed control on the growth and developent of cowpea.}

At $6 \mathrm{WAS}$, lower insecticide rate produced more vigorous cowpea crops than the higher insecticide rates at $\mathrm{T} \& \mathrm{R}$ farm and the mean, however at 9 WAS both rates produced crops, that was significantly more vigorous than crops that were not treated with insecticide at Ga-Alanu (Table 5). Both insecticide rates produced significantly taller plants in Ga-Alanu at 12 WAS than crops that were not treated with insecticide (Table 6). Similarly, 
the method of weed control did not significantly affect plant height of cowpea throughout the life cycle of the crop. There was no interaction effect of insecticide rates and method of weed control on plant height of cowpea (Table 6). Both lower and higher Lambda cyhalothrin insecticide rates produced significantly taller and more vigorous cowpea crops than crops that were not treated with insecticide at 9 WAS and 12 WAS respectively in Ga-Alanu. This phenomenon could be as a result of the ability of the insecticide at the two rates to effectively control insects attacking the

Table 5. Effect of Lambda cyhalothrin insecticide rate and methods of weed control on cowpea crop vigour.

\begin{tabular}{|c|c|c|c|c|c|c|}
\hline \multirow[b]{3}{*}{ Insecticide rate (I) (g a.i./ha) } & \multicolumn{6}{|c|}{ Crop Vigour } \\
\hline & \multicolumn{3}{|c|}{$6 \mathrm{WAS}^{1}$} & \multicolumn{3}{|c|}{12 WAS } \\
\hline & T\&R & GA & Mean & T\&R & GA & Mean \\
\hline $\mathrm{C}_{\mathrm{H}}$ & 7.25 & 6.83 & 7.04 & 8.14 & 7.78 & 7.96 \\
\hline 8.75 & 7.53 & 7.50 & 7.51 & 8.28 & 8.39 & 8.33 \\
\hline 17.5 & 6.39 & 7.22 & 6.81 & 8.08 & 8.28 & 8.18 \\
\hline $\operatorname{LSD}(0.05)$ & 0.64 & 0.72 & 0.68 & 0.60 & 0.51 & 0.56 \\
\hline \multicolumn{7}{|l|}{ Methods of Weed Control(WC) } \\
\hline Weeding 3 \& 6 WAS & 7.11 & 6.72 & 6.92 & 8.39 & 7.94 & 8.17 \\
\hline Melachlor+Diuron1.5+0.6 kg a.i./ha & 7.06 & 7.28 & 7.17 & 8.33 & 8.22 & 8.28 \\
\hline Pedimethalin 1.5 kg a.i./ha & 7.06 & 7.28 & 7.17 & 8.17 & 8.22 & 8.19 \\
\hline Pedimethalin 1.5 kg a.i./ha+one SHW 6WAS & 7.11 & 7.39 & 7.25 & 8.17 & 8.28 & 8.22 \\
\hline Pedimethalin 2.0 kg a.i./ha & 7.28 & 7.33 & 7.31 & 8.33 & 8.22 & 8.28 \\
\hline Weedy Check & 6.72 & 7.11 & 6.92 & 7.61 & 8.00 & 7.81 \\
\hline $\operatorname{LSD}(0.05)$ & 0.91 & 1.01 & 0.96 & 0.83 & 0.72 & 0.78 \\
\hline \multicolumn{7}{|l|}{ Interaction } \\
\hline $\mathrm{I}^{*} \mathrm{WC}$ & NS & NS & & NS & NS & \\
\hline
\end{tabular}

WAS=Weeks after sowing, $\mathrm{NS}=$ Not significant, $\mathrm{GA}=\mathrm{Ga}-\mathrm{Alanu}$ Village, $\mathrm{T} \& \mathrm{R}=$ Teaching and Research Farm.

Table 6. Effect of Lambda cyhalothrin insecticide rates and methods of weed control on cowpea plant height.

\begin{tabular}{|c|c|c|c|c|c|c|c|c|c|}
\hline \multirow{3}{*}{$\begin{array}{c}\text { Treatment } \\
\text { Insecticide rate (I) (g a.i./ha) }\end{array}$} & \multicolumn{9}{|c|}{ Plant height $(\mathrm{cm})$} \\
\hline & \multicolumn{3}{|c|}{$6 \mathrm{WAS}^{1}$} & \multicolumn{3}{|c|}{9 WAS } & \multicolumn{3}{|c|}{ Harvest } \\
\hline & T\&R & GA & Mean & T\&R & GA & Mean & T\&R & GA & Mean \\
\hline 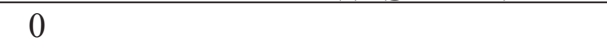 & 46.80 & 46.21 & 46.51 & 64.29 & 67.54 & 65.92 & 62.42 & 63.70 & 63.06 \\
\hline 8.75 & 43.01 & 47.41 & 45.21 & 59.63 & 72.81 & 66.22 & 58.44 & 61.07 & 59.76 \\
\hline 17.5 & 44.20 & 41.08 & 42.64 & 66.28 & 60.91 & 63.59 & 60.90 & 55.46 & 58.18 \\
\hline $\operatorname{LSD}(0.05)$ & 3.64 & 5.55 & 4.59 & 5.55 & 15.32 & 10.44 & 5.23 & 4.90 & 5.07 \\
\hline \multicolumn{10}{|l|}{ Methods of Weed Control (WC) } \\
\hline Weeding 3 \& 6 WAS & 44.84 & 41.18 & 43.01 & 64.98 & 66.28 & 65.63 & 63.07 & 57.58 & 60.32 \\
\hline Melachlor+Diuron1.5+0.6 kg a.i./ha & 43.22 & 46.90 & 45.06 & 63.82 & 65.51 & 64.67 & 58.67 & 64.18 & 61.42 \\
\hline Pedimethalin 1.5 kg a.i./ha & 44.24 & 47.44 & 45.84 & 66.93 & 66.71 & 66.82 & 62.58 & 59.82 & 61.20 \\
\hline Pedimethalin 1.5 kg a.i.//ha+one SHW 6WAS & 43.71 & 43.71 & 43.71 & 60.32 & 66.56 & 63.44 & 59.67 & 60.51 & 60.09 \\
\hline Pedimethalin 2.0 kg a.i./ha & 47.16 & 45.56 & 46.36 & 64.31 & 67.27 & 65.79 & 62.93 & 58.33 & 60.63 \\
\hline Weedy Check & 44.84 & 44.60 & 44.72 & 60.02 & 70.20 & 65.11 & 56.62 & 60.02 & 58.32 \\
\hline LSD (0.05) & 5.14 & 7.85 & 6.49 & 7.85 & 21.66 & 14.76 & 7.40 & 6.93 & 7.17 \\
\hline \multicolumn{10}{|l|}{ Interaction } \\
\hline $\mathrm{I} * \mathrm{WC}$ & NS & NS & & NS & NS & & NS & NS & \\
\hline
\end{tabular}

WAS $=$ Weeks after sowing, $\mathrm{NS}=$ Not significant, $\mathrm{GA}=\mathrm{Ga}-\mathrm{Alanu}$ Village, $\mathrm{T} \& \mathrm{R}=$ Teaching and Research Farm. 
cowpea crop at the vegetative growth stage, like Oetheca mutabulis, sap-sucking bugs and other pre-flowering insects of cowpea which could have enhanced the vigor and growth of the crop.

\section{Effect of Lambda cyhalothrin rates and methods of weed control on the yield component and grain yield of cowpea}

Insecticide rate significantly increased the number of pods/plant compared to plots not treated with insecticide at both T\&R farm and Ga-Alanu and their mean at 9 WAS. The same observation was recorded only at Ga-Alanu at 12 WAS as cowpea that was not treated with insecticide produced significantly lower pods than that treated with insecticide (Table 7).Similarly, pendimethalin at $2.0 \mathrm{~kg}$ a.i. ha $\mathrm{h}^{-1}$ gave a significantly higher number of pods/plant in both T\&R farm and the mean which was comparable to the other methods of weed control only at the average weedy check gave significantly lower pods/plant. At harvest pendimethalin at $1.5 \mathrm{~kg}$ a.i.ha ${ }^{-1}$ plus one SHW produced significantly higher number of pods/plant in T\&R farm and Ga-Alanu, which was comparable only to other weed control methods except for metolachor+diuron at $1.5+0.6 \mathrm{~kg}$ a.i.ha ${ }^{-1}$ at $\mathrm{T} \& \mathrm{R}$ farm, pendimethalin at $1.5 \mathrm{~kg}$ a. i. ha ${ }^{-1}$ at Ga-Alanu and metolachor+diuron at $1.5+0.6 \mathrm{~kg}$ a. i. ha ${ }^{-1}$. The interaction between Lambda cyhalothrin rates and method of weed control was not significant.

Insecticide rates had a significant effect on grain yield only in T\&R farm and the mean but not in Ga-Alanu (Table 7). Lower application rate of Lambda cyhalothrin produced significantly higher yield than zero insecticide treatment but was comparable with higher rate of Lambda cyhalothrin (Table 7). Similarly, pendimethalin at $1.5 \mathrm{~kg}$ a.i. ha-1 plus one SHW produced significantly highest grain yield than the weedy check at T\&R farm which was comparable with the other methods of weed control except pendimethalin at $1.5 \mathrm{~kg}$ a.i. ha ${ }^{-1}$, metolachlor +diuron at $1.5+0.6 \mathrm{~kg}$ a.i. ha ${ }^{-1}$ and weedy check at $\mathrm{T} \& \mathrm{R}$ farm which produced significantly lower grain yield. Generally, the grain yield at Ga-Alanu was higher than T\&R farm. Insecticide rates

Table 7. Effect of Lambda cyhalothrin insecticide rate and method of weed control on cowpea number of pods and grain yield.

\begin{tabular}{|c|c|c|c|c|c|c|c|c|c|}
\hline \multirow{3}{*}{$\begin{array}{c}\text { Treatment } \\
\text { Insecticide rate (I) (g a.i./ha) }\end{array}$} & \multicolumn{9}{|c|}{ Number of Pods } \\
\hline & \multicolumn{3}{|c|}{9 WAS } & \multicolumn{3}{|c|}{ Harvest } & \multicolumn{3}{|c|}{ Grain yield } \\
\hline & T\&R & GA & Mean & T\&R & GA & Mean & T\&R & GA & Mean \\
\hline 0 & 17.19 & 19.60 & 18.39 & 23.88 & 22.02 & 22.95 & 231.49 & 720.61 & 476.05 \\
\hline 8.75 & 23.77 & 25.98 & 24.87 & 20.07 & 28.54 & 24.31 & 436.63 & 1125.07 & 780.85 \\
\hline 17.5 & 25.52 & 29.67 & 27.59 & 20.19 & 29.07 & 24.63 & 253.11 & 1092.09 & 672.60 \\
\hline LSD (0.05) & 4.45 & 5.44 & 4.94 & 4.63 & 3.89 & 4.26 & 101.77 & 447.53 & 274.65 \\
\hline \multicolumn{10}{|l|}{ Methods of Weed Control (WC) } \\
\hline Weeding $3 \& 6$ WAS & 19.44 & 24.24 & 21.84 & 25.67 & 28.13 & 26.90 & 367.26 & 946.47 & 656.86 \\
\hline Melachlor+Diuron $1.5+0.6$ kg a.i./ha & 21.56 & 27.80 & 24.68 & 15.44 & 28.22 & 21.83 & 313.72 & 1047.87 & 680.79 \\
\hline Pedimethalin 1.5 kg a.i./ha & 23.49 & 25.78 & 24.63 & 23.47 & 23.69 & 23.58 & 237.44 & 835.53 & 536.49 \\
\hline $\begin{array}{l}\text { Pedimethalin } 1.5 \text { kg a.i./ha+one } \\
\text { SHW 6WAS }\end{array}$ & 20.76 & 25.49 & 23.12 & 24.93 & 29.22 & 27.08 & 432.66 & 1071.78 & 752.22 \\
\hline Pedimethalin 2.0 kg a.i./ha & 29.84 & 23.09 & 26.47 & 21.69 & 26.82 & 24.26 & 329.44 & 1119.16 & 724.30 \\
\hline Weedy Check & 17.87 & 24.09 & 20.98 & 17.07 & 23.18 & 20.12 & 161.93 & 854.74 & 508.34 \\
\hline $\operatorname{LSD}(0.05)$ & 6.29 & 7.70 & 6.99 & 6.54 & 5.50 & 6.02 & 143.93 & 632.9 & 388.42 \\
\hline \multicolumn{10}{|l|}{ Interaction } \\
\hline $\mathrm{I}^{*} \mathrm{WC}$ & NS & NS & & NS & NS & & NS & NS & \\
\hline
\end{tabular}

WAS=Weeks after sowing, $\mathrm{NS}=$ Not significant, $\mathrm{GA}=$ Ga-Alanu Village, $\mathrm{T} \& \mathrm{R}=$ Teaching and Research Farm. 
significantly increased the number of pods in the cowpea in both T\&R farm and Ga-Alanu at 9 and 12 WAS, respectively. This indicates probably that the tested rates of insecticide were effectiveness to control insects that attack flower thrips, pod borers and sucking-bugs (Jackai and Daoust, 1986; Ogunwolu 1990; Badii et al., 2008). These insects could destroy the pods and reduce the grain yield of cowpea. Pre-emergence application of pendimethalin at $2.0 \mathrm{~kg}$ a.i.ha ${ }^{-1}$ and pendimethalin at $1.5 \mathrm{~kg}$ a.i.ha ${ }^{-1}$ plus one SHW gave significantly higher number of pods, which was comparable with other methods of weed control. The pendimethalin at $1.5 \mathrm{~kg}$ a.i.ha ${ }^{-1}$ and a tank mixture of metolachlor + diuron at $1.5+0.6 \mathrm{~kg}$ a.i.ha ${ }^{-1}$ gave significantly lower number of pods. This fact could be due to the ability of above methods of weed control to minimize weed infestation which reduced weed competition and allowed the crop to utilize an adequate amount of growth resources for growth and higher yield. Besides that, the effective control of weeds by the above methods of weed control could have minimized the insect population and reduced attack and destruction by pests. Other workers have reported better crop yields with integrated use of herbicides with hand weeding. (Peer et al., 2013; Veeramani et al., 2001; Imoloame, 2014).

Both insecticide rates increased grain yield significantly at the T\&R farm but not in Ga-Alamu because of the effectiveness of the insecticide in controlling both pre-flowering, flowering and postflowering pests which led to enhanced growth, development, and productivity of cowpea crop. Tabuzil (1991) and Dzemo et al. (2010), obtained a significantly higher grain yield in insecticide-treated plots than control plots. Furthermore, Omongo and Adipala (1998) reported that the higher grain yield in the insecticide treatments might be due to the reduction in the abundance of the major insect pest and their subsequent damage to the cowpea crop as a result of the insecticidal activity. The effectiveness of the two rates of insecticide combined with significantly low weed infestation caused by the application of pendimethalin at $1.5 \mathrm{~kg}$ a.i. ha ${ }^{-1}$ plus one SHW constituted an effective pest management system that could have further led to higher grain yield of cowpea. The higher grain yield recorded in Ga-Alanu compared to T\&R farm could be due to the higher weed pressure at the T\&R farm which could have resulted in more weed competition and insect attack and destruction

In conclusion, for effective control of pests (weeds and insect) and higher yield of cowpea grain yield, pendimethalin at $1.5 \mathrm{~kg}$ a.i. ha ${ }^{-1}$ plus one SHW, or pendimethalin at $2.0 \mathrm{~kg}$ a.i ha ${ }^{-1}$ with a minimum application of Lambda cyhalothrin at $8.75 \mathrm{~g}$ a.i. $\mathrm{ha}^{-1}$ or $17.5 \mathrm{~g}$ a.i.ha $\mathrm{a}^{-1}$ is suitable. However, in other to minimize environmental pollution and pesticide residue in the cowpea grain, pendimethalin at $1.5 \mathrm{~kg}$ a.i.ha ${ }^{-1}$ integrated with one SHW at 6 WAS and application of the lower rate of lambda cyhalothrin insecticide at 8.75 g.a.i.ha ${ }^{-1}$ are found to be more suitable.

\section{References}

Akinyemiju, O.A.; Olaifa, J.A. Relative importance of weeds and insect pests control in cowpea production In: Cowpea Production. Nigerian Journal of Weed Science, v.4, p.43-53, 1991.

Amatobi, A.M.; Dike, M.C.; Opareke, A.M. Integrated pest management of thrips and maruca on cowpea at samaru cropping scheme meeting. Zaria, Nigeria: Ahmadu Bello University, 2005.

Report on Legume and Oil Seed Research Programme, v.5, p.23-24.

Amosun, J.O.; Ayeni, A.O.; Tijani-Eniola, H.; Majek, B.A. Influence of tillage on herbicide efficacy in maize in south western Nigeria. Nigerian Jounal of Weed Science, v.29, p.41-55, 2016.

Asiwe, J.A.N. Recent progress in cowpea breeding in Agricultural Research Council (ARC) - Grain Crop Institute. Potchefstroom, South Africa. In: International Conference on Indigenous Vegetables and Legumes: Prospects for fighting poverty, 
hunger and malnutrition, 1., 2007, Hyderabad, India. Proceedings... Hyderabad, India: ISHS, 2007a. p.381-385.

Asiwe, J.A.N. Baseline survey on the production, constraints and Utilization of cowpea in South African: Implications to cowpea Improvements. In: International Conference on Indigenous Vegetables and Legumes. Prospects for fighting poverty, hunger and malnutrition, 1., 2007, Hyderabad, India. Proceedings... Hyderabad, India: ISHS, 2007b. p.621-622.

Asiwe, J.A.N. Insect mediated out crossing and gene flow in Cowpea (Vigna Unguiculata (L) Walp): implication for seed production and provision of containment structures for GT cowpea. African Journal of Biotechnology, v.8, n.2, p.226-230, 2009b. Available from: $<$ http:// www.academicjournals.org/AJB $>$. Accessed: 07 mar. 2017.

Asiwe, J.A.N. Performance of exotic cowpea varieties for grain and fodder production in South Africa. In: Plant Breeders Association Symposium, 1., 2008, Drakensbery, South Africa. Abstract... Drakensbery, South Africa, 2008. p.620-623.

Asiwe, J.A.N.; Nokoe, S.; Jackia, L.E.N.; Ewete, F.K. Does varying cowpea spacing provide better protection against cowpea pests? Crop Protection (Guildford, Surrey), v.24, p.465-470, 2005.

Badii, B.K.; Asante, S.K.; Ayertey, Y.N. Field evaluation of neem extracts for the control of major pests of cowpea in NorthernGhana. Ghana Journal of Agricultural Science, v.41, n.2, p.191-202, 2008.

Badii, K.B.; Bae, A.; Sowley, E.N.K. Efficacy of some Lambda-cyhalothrin - based insecticides in the control of major field pests of cowpea (Vigna unguiculata L). International Journal of Science and Technology Research, v.2, n.4p, p.76-81, 2010.

CGIAR. Cowpea (Vigna unguiculata). Research: areas of research. Washington, DC, 2001. Available from: <http:/www.cgiar.org.research/res-cowpea. html>. Accessed: 07 mar. 2017.

Chatta, M.R.; Jamil, M.; Mahmood, Z.T. Yield and Yield Components of cowpea as affected by various weed control methods under rain-fed conditions of Pakistan. International Journal of Agriculture and Biology v.9, n.1 p.120-124, 2007.

Das, T.K. Weed science basics and applications. Jain Brothers, 2011. 907p.

Davis, D.W.; Oelke, E.A.; Oplinger, E.S.; Doll, J.D.; Hason, C.V.; Putnam, D.H. Cowpea: alternative field crop manual. Centre for alternative plant and animal product. Madison, USA: University of Wisconsin, 2005.

Dugje, I.Y.; Omoigui, L.O.; Ekeleme, F.; Kamara, A.Y.; Ajeigbe, H. Farmers' guide to Cowpea production in West Africa. Ibadan, Nigeria: International Institute of Tropical Agriculture, 2009. 19p.

Dzemo, W.D.; Niba, A.S.; Asiwe, J.A.N. Effects of Insecticide spray application on insect infestation and yield of Cowpea (Vigna Unguiculata (L) Walp) in the Traskei, South Africa. African Journal of Biotechnology, v.9, p.1673-1679, 2010.

Ezuueh, M.I.; Amusah, L.O. Cowpea Insect damage as influenced by the presence of weeds. Agric, Ecosyst and Environ, v.21, n.2, p.255263, 1988.

FAO - Food and Agriculture Organization of the United Nations. FAOSTAT Agricultural data 2001. Available from: $<$ http://aps.fao.org.egi-bin/nph-db. pl?subset-agriculture >. Accessed: 07 mar. 2017.

Gani, M.; Mahadi, M.A.; Dadari, S.A.; Babaji, B.A.; Shinggu, C.P. Weed Flora and Importance Value Index (IVI) of Finger Millet (Eleusine Coracana (L) Gaetn) in the Northern Guinea and Sudan Savannas of Nigeria. Nigerian Journal of Weed Science, v.29p, p.10-18, 2016.

Imoloame, E.O. Weed control and yield of soybeans (Glycine Max (L) Merril) in the southern Guinea 
savanna of Nigeria. Nigerian Journal of Weed Science, v.27p, p.40-52, 2014.

Jackai, E.N.; Daoust, R.A. Insect pest of cowpea. Annual Review of Entomology, v.31, p.95-119, 1986.

Jefferson, T. Cowpea: a versatile crop for hot dry conditions. West Nifong, Colombia: Thomas Jefferson Agricultural Institute, 2005. p.246.

Li, R.; Guidong, Z.; Yumei, Z.; Zhanzhi, X. Damage loss and control technology of weeds in cowpea field. Weed Science, v.2, p.25-26, 2004.

Longdale, G.W.; Clarke, R.L.; Bruce, R.R. The role of legumes in sustaining soil productivity and controlling soil erosion. In: Mulongoy, M.; Gueye, K.; Spencer, D.S.C. (Ed.). Biological nitrogen fixation and sustainability of tropical agriculture. Ibadan, Nigeria: JLTA, 1992. p.361-366.

Mulongoy, K. Nitrogen fixing symbiosis and tropical ecosystems. In: Singh, S.R.; Rachie, K.O. (Ed.). Cowpea research, production and utilization. London, UK: John Wiley and Sons, 1995. p.307-325.

Obeng-Ofori, D. Pests of grain legumes. In: Obeng-Ofori, D. (Ed.). Major pest of food and selected fruits and industrial crops in West Africa. The City Publisher Ltd., 2007. p.82-93.

Ogunwolu, E.O. Damage to cowpea by the legume pod borer, Maruca Testulalis Geyer, as influenced by infestation density in Nigeria. Tropical Pest Management, v.36, n.2p, p.230-337, 1990.

Omongo, C.A.; Adipala, E.; Ogenga-Laatigo, O.; Kyamanywa M.W. A Insecticide application to reduce pest infestation and damage in cowpea in Uganda. African Plant Protection, v.4, n.2, p.91-100, 1998.

Peer, F.A.; Badrul Leone, B.A.; Qayoom, S.; Ahmed, L.; Khanday, B.A.; Singh, P.; and Singh, G. Effeect of weed control methods on yield and yield attributes of soybean. African Journal of
Agricultural Research. v. 8, n.48, p.6135-6141, 2013

Quin, F.M. Introduction. In; Singh, B.B.; Mohan Raj., D.R., Dashiell, K.E. and Jackai, L.E.N.( eds.). Advances in Cowpea Research. Sayce Publishing, Devon, U.K., p. ix-xv,1997.

Rachie, K.O. Introduction. In: Singh, S.R.; Rachie, K.O. (Ed.). Cowpea research, production and utilization. London, UK: John Wiley and Sons, 1985. p.xxv-xxviii.

Rusoke, D.G.; Rubaihayo, P. The influence of some crop protection management practices on yield stability of cowpea. African Crop Science Journal, v.2, p.143-148, 1994.

Singh, S.R. Insect pests of tropical food crops. Ibadan: John Willey and Sons, 1990.

Singh, B.B.; Asante, K.; Ajegbe, H.; Mohammed, S.H. General guide for cowpea cultivation and seed production sakakawa global 2000. Abuja: Federal Ministry of Agriculture, 2000.

Singh, B.B.; Hartmann, P.C.; Fotokun, M.; Tamo, S.; Tarawale, R. Ortiz recent progress on cowpea improvement. Chronica Horticulture, v.43, p.8-12, 2003.

Singh, S.R.; Jackai, L.E.N. Insect pest of cowpea in Africa: their life cycle, economic importance and potential for control. In: Singh, S.R.; Rachie, K.O. (Ed.). Cowpea research production and utilization. New York: John Wiley and Sons, 1985. p.217-231.

Tabuzil, P.B. The Control of insect pests of cowpea with neem (Azadiracta Indica) in northern Ghana. Tropical Pest Management, v.37, n.3, p.216-217, 1991.

Takim, F.O.; Uddin II Effect of weed removal on insect population and yield of cowpea (Vigna unguiculata (L.) Walp). Journal of Agricultural Engineering, v.1, n.5, p.194-199, 2010.

Tarawali, S.A.; Singh, B.B.; Peters, M.; Blade, S.F. Cowpea haulms as fodder. In: Singh, B.B.; 
Mohan Raj, D.R.; Dashiell, K.E.; Jackai, L.E.N. Veeramani, A.; Palchamy, A.; Ramasamy, S.; (Ed.). Advances in cowpea research. Devon, Rangaraju, G. Integrated weed management in UK: Sayce Publishing, 1997. p.313-325. soybean (Glycine max(L.) Merril) under various The Guardian. September, 2, 2016. Available from: plant densities. The Madras Agricultural Journal, <guardian.ng/.../expert-agent-tasks-government- v.88, n.7-9, p.451-456, 2001. on-ending-rejection-of-nigerian beans $>$. Accessed: 07 mar. 2017.

Tripathi, S.S.; Singh, G. Critical period of weed competition in summer cowpea (Vigna unguiculata L.) India Journal of Weed Science, v.33, p.67-68, 2001.

Wenthworth, T.R.; Conn, J.S.; Skroch, W.A.; Mrozek Junior, E. Gradient analysis and numerical classification of apple orchards and weed vegetation. Agriculture, Ecosystems \& Environment, v.11, n.3, p.239-251, 1984. 